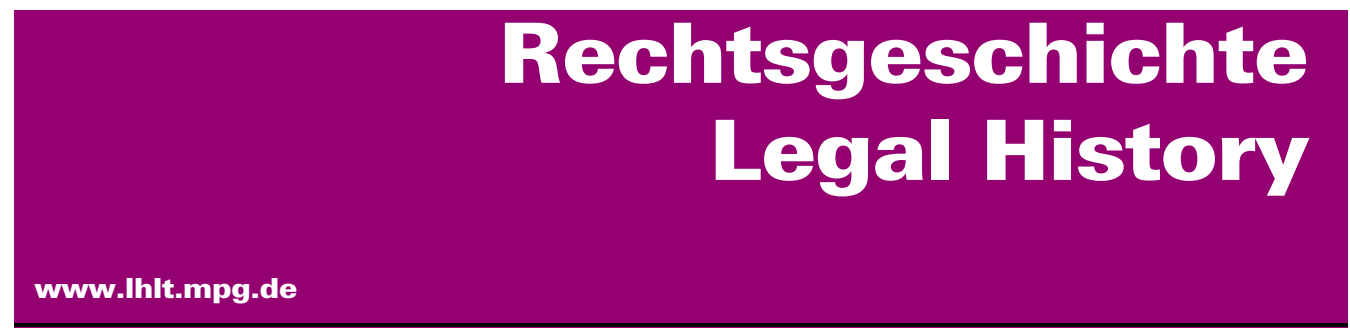

http://www.rg-rechtsgeschichte.de/rg29

$\operatorname{Rg} 292021 \quad 322-325$

Zitiervorschlag: Rechtsgeschichte - Legal History Rg 29 (2021)

http://dx.doi.org/10.12946/rg29/322-325

Benedetta Albani *

Alexandra Anokhina**

Francesco Giuliani ***

Anna Clara Lehmann Martins ****

\title{
Reinterpreting the Counter-Reformation from the Ibero-American Perspective
}

* Max Planck Institute for Legal History and Legal Theory, Frankfurt am Main, albani@lhlt.mpg.de

* Max Planck Institute for Legal History and Legal Theory, Frankfurt am Main, anokhina@lhlt.mpg.de

*** Max Planck Institute for Legal History and Legal Theory, Frankfurt am Main, giuliani@lhlt.mpg.de

***: Max Planck Institute for Legal History and Legal Theory, Frankfurt am Main, martins@lhlt.mpg.de

Dieser Beitrag steht unter einer Creative Commons Attribution 4.0 International License

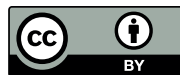


romaine, aux relations diplomatiques entre le Saint-Siège et les États, au statut et aux prérogatives des cardinaux (même si les sources canoniques, à l'exception des traités de Giovanni Battista De Luca, sont peu sollicitées) et à la gestion de leur patrimoine privé, ainsi que sur des aspects jusquelà davantage délaissés par l'historiographie mais très stimulants, appelant des approfondissements ultérieurs, à l'exemple des protectorats exercés par les cardinaux sur les confréries et instituts religieux, ou des enjeux liés à la détention du titre - diaconie, église ou évêché suburbicaire - qui leur est assigné par le pape en consistoire lors de leur création. Loin d'une représentation, somme toute classique, des cardinaux comme simples "créatures" des papes et leur demeurant subordonnées, cette vaste synthèse - augmentée d'une riche et très utile bibliographie placée en fin de volume (617-686) dresse un panorama complet des nombreux rôles et fonctions assumés par les cardinaux au sein d'un milieu romain non exclusivement ecclésiastique, au sein d'une société de cour, celle de l'entourage pontifical, au sein d'un appareil gou- vernemental en voie de profond renouvellement, au sein d'un État pontifical en mutation, et enfin au cour de rapports de force internationaux et d'activités missionnaires auxquels le Saint-Siège s'efforce de donner des orientations conformes aux principes tridentins.

C'est peut-être ce caractère de visibilité des cardinaux, celle individuelle de Princes de l'Église mais aussi celle institutionnelle de hauts responsables ecclésiastiques - une élite romaine et du monde, saisissable à diverses échelles - marqué et renforcé par le port du chapeau ou de la barrette rouge, qui fait mieux saisir le sens de la fameuse décision adoptée par Urbain VIII en 1630 de leur accorder l'usage du titre d'Éminence, acteurs majeurs et figures centrales d'instances atteignant elles-mêmes, au long de la période considérée, un degré inédit de centralisation. En cela, il est aussi l'un des marqueurs les plus fiables d'une modernité ecclésiale dont les signes et les manifestations institutionnelles comme symboliques ici - excèdent la seule dynamique posttridentine.

\section{Benedetta Albani, Alexandra Anokhina, Francesco Giuliani, Anna Clara Lehmann Martins Reinterpreting the Counter-Reformation from the Ibero-American Perspective*}

The Counter-Reformation is a historiographical category which is associated with the profound changes that took place within the Catholic Church from the 16th century onwards. Since the mid-20th century, European and North American historians have ceased to identify the CounterReformation exclusively as a reaction of Catholicism against the influxes of Protestantism. The alternative interpretation posed by scholars such as Hubert Jedin (and later on Ronnie Po-Chia Hsia and John W. O'Malley) is that Catholic reformist impulses ran in parallel to - and even preceded Luther's Reformation, corresponding to an autonomous, complex movement, with a variety of forms of expression.

With regard to law, the most impactful change related to the Counter-Reformation was the Council of Trent (1545-1563). Among other things, this normative corpus established a new disciplinary paradigm for the Catholic clergy and laity that

\footnotetext{
Macarena Cordero, Jorge Cid (eds.), Contrarreforma católica, implicancias sociales y culturales: Miradas interdisciplinarias, Santiago de Chile: Editorial Cuarto Propio 2019, 404 p., ISBN 978-956-396-068-6
} 
lasted for over three centuries. Not by chance, the historiography on the Counter-Reformation encompasses a wide range of approaches to the Council of Trent, from the monumental pictures of its genesis to the specific studies on its adaptation to local contexts. The book Contrarreforma católica, implicancias sociales y culturales: Miradas interdisciplinarias, edited by Macarena Cordero and Jorge Cid, now joins this historiography. Bringing together articles written mostly by young researchers, this work seeks to offer, in an interdisciplinary fashion, fresh contributions on the Counter-Reformation, the Council of Trent and the heterogeneity of its effects in the Ibero-American territory.

The book is structured in four sections. With the absence of section titles, the reader is invited to put forward her/his own interpretation on the connections (and disconnections) between the articles; this is also what we attempt with this review.

The first section of the book is dedicated to broad aspects of intellectual history: constructing the image of the ideal clergy, the narrative identity approach applied to Biblical reading practices, and early modern political thought. The contribution of Fermín Labarga focuses on 16th-century Spanish priest Fernando Contreras as an exemplary figure. The discussion on post-Tridentine actors as role models (or anti-models) - be they bishops or parish priests, friars or nuns, ecclesiasticals or laymen, men or women, some portrayed as embodiments of the Counter-Reformation values, others as negative, deviating examples - interests other authors in the book. For his part, Labarga examines the trajectory of clergyman Contreras, in particular his labor in the rescue of captive Christians and the conversion of Muslims in Africa. The author relies on the testimonies from Algiers, Tétouan and Ceuta that were attached to the canonical process that led Contreras to be entitled venerable by Pope Pius VI in 1786. In the second article, Mike von Treek approaches how the Counter-Reformation established specific conditions for the practice of reading the Scripture, giving room to long-lasting models of more and less »apt readers«. While comparing reading practices in Protestant and Catholic contexts, von Treek recognizes in the Counter-Reformation the origin of problems that became very strong and manifest from the 19th century to present day. Among them is the marginalization of the Biblical readings of the uneducated, the poor, women, indigenous persons, non-
Catholics etc., in sum, of all groups that do not fit in the Counter-Reformist "apt reader model « (an educated, male, European priest). This section closes with an essay by Felipe Schwember, who explores the link between Salmantine political philosophers and modern contractualism. The author focuses on the School of Salamanca's interpretation of the social contract. The views of Salamanca's theologians on Aristotelian and Aquinian thought are at the centre of this text. In particular, the author investigates the role of the concept of natural law in the development of the idea of political freedom.

The book's second section revolves around one of the famous foes of Counter-Reformation: Protestantism. It discusses Protestants' points of view and points of view on Protestantism. The article by Bettine Baader focuses on the latter, more precisely on the relationship between Protestant Reformation and Max Weber's thesis on the Disenchantment of the World, a relationship often taken for granted even by present day historians. With a methodologically stimulating text, Baader demonstrates that the Disenchantment refers not to the whole Reformation, but to Calvinism - and, in particular, to Weber's own portrait of it, a portrait which, with little support of historical sources and much reliance on intuitive methods, contained generalizations and anachronisms typical of 19th-century progressive views on history. Baader's article stands as a reminder of the relevance of historical context to a proper assessment of the qualities and limits of theories. The next contribution belongs to the category of Protestants' points of view. Diego Melo Carrasco approaches the perspective of Martin Luther on Islam, based on the prologue that the reformist wrote to Bibliander's edition of the Koran. Presenting a topic little explored by historiography, Carrasco's text shows that the horizon of concerns of the Reformation's leaders went beyond the critique of the Catholic Church, challenging, to some extent, the perfect action/reaction relationship between Reformation and CounterReformation. The section closes with Ana Hontanilla's account of how reports from 18th-century British travelers used to picture Spain as a barbaric territory. The connection established in these documents between barbarism and Catholic institutions (above all, the Inquisition), besides evoking the liberal context of the travellers (many of them, one may suppose, of Protestant descent), recalls the negative, regressive connotation that Protestant 
historians would attach to the category of CounterReformation one century later.

If one of the book's aims is to offer an account of the variety of uses and interpretations of the Council of Trent in Ibero-America, going against discourses that address the Counter-Reformation as a homogeneous phenomenon on both sides of the Atlantic, this objective meets an organized though at times superficial - fulfillment in the book's third section. It is, moreover, a section that displays at its best the interdisciplinary potential of Counter-Reformation as a research field, for its articles present subjects closely related to the arts (painting, literature, music) and, at the same time, offer a rich overview of intertwining elements from politics, ecclesiastical administration and economy. Through the section, the diversity of (cultural) translations of the Council of Trent in Ibero-American space is explained by factors such as: (i) the adoption of varied post-Tridentine literature by local actors during the elaboration of local normative corpora, as seen in Fernando Guzmán's text about the Tridentine doctrine on sacred images in Ibero-American synods and provincial councils; (ii) the survival and transformation of indigenous elements (contraconquista elements) in contexts of evangelization, as allowed by the mimetic potential of Catholicism, as claimed by Luz Ángela Martínez in her analysis of the groundbreaking poetic work of Sor Juana Inés de la Cruz, and as present in Daniel Astorga's account on the process of assimilation of Mictlan into Christian Hell in Fray Andrés de Olmos' Tratado sobre los siete pecados mortales, both cases from Nueva España; (iii) the persistence of "misunderstandings « about what the Council of Trent actually disposed, in addition to the necessity of adapting Tridentine precepts to local limitations of personnel and material, as pointed by Laura Fahrenkrog, in her text about musical practices in Asunción del Paraguay. This section also includes Jorge Cid's reflections on the formal bridges between the Counter-Reformation alias in the arts, the Baroque, and 20th-century Neo-Baroque.

Moving to the fourth and final section, two articles are more closely related to the functioning of ecclesiastical and secular jurisdictions in the late modern age. These are the contributions of Nelson Castro Flores and Macarena Cordero Fernández. The remaining texts, by Mario Prades Vilar and Mariana Labarca Pinto, focus on the so-called actors of the post-Tridentine period. Castro Flores' work is part of the broad debate on the original adaptations that the Council of Trent received in local context. The author proposes the category of episcopal reformism to address the central role of bishops in local reforming processes in the Archbishopric of La Plata during the 18th century, in particular in the field of indigenous evangelization. The main objects of his analysis are the normative efforts of bishops to eradicate superstition and foster intimate, personal forms of devotion among the natives. It is noteworthy that, even though historiography usually emphasizes the conflicts between the papacy and secular powers during this period, Castro Flores claims that Bourbon regalism and Pope Benedict XIV's renovación cristiana would have converged towards the development of episcopal reformism. Such a bold assertion gives a wider, interconnected, even global flavor to his local-level narrative. Still in the realm of jurisdictions in postTridentine times, Macarena Cordero's article focuses on the approach that different foros de justicia had towards bigamy in 18th-century Chile. Due to its complex character - encompassing sin, crime and an »open door" to heresy - bigamy was then under the competence of three foros: the ecclesiastical court, the secular court, and the Inquisition. While analyzing three paradigmatic cases, Cordero offers a comprehensive and comparative overview of the activity of the three jurisdictions, emphasizing their distinct procedures, solutions and aims. The article of Prades Vilar in turn approaches an unexpected actor among post-Tridentine exemplary figures: the Jesuit model of the Christian soldier. By employing the historiographical category of confessionalization, Prades Vilar expands the borders of classical studies on evangelization, usually limited to the relations between missionaries, evangelizers and indigenous communities. Instead, he analyses the complex process of evangelization of Spanish soldiers by the Society of Jesus in Chile between the 16th and 17th centuries. Finally, in Mariana Labarca Pinto's chapter we meet yet another group of Tridentine actors: the nuns. The author's point of observation is the history of science and medicine. More precisely, Labarca Pinto exposes how physicians interpreted and treated hysterical disorders perceived in Italian convents during the 18th century. Attentive to the changes also in the discourse of the nuns as patients, this text proposes an interesting reflection on how 18th-century medicine connected the roots of psychological disorders not to supernat- 
ural causes, but to elements such as violence and sleep deprivation in Catholic convents - arguments that we usually associate with 20th-century psychiatry.

In general, Cid and Cordero's book is successful in displaying many concepts established around the Council of Trent by different research fields. The articles comprise both concepts with a longstanding presence in the history of religions and the history of art (Counter-Reformation, Baroque) and new constructions (Contraconquista, episcopal reformism, Neo-Baroque, etc.). This conceptual variety mirrors the diversity of approaches and interpretations present in the work. However, the absence of a common understanding on the meaning of Counter-Reformation among the authors, or perhaps the absence of an introductory discussion on the history of Counter-Reformation as a historiographical category poses many questions to the readers. Through the articles, one often wonders: what is understood as Counter-Reformation by this author? In the period between the Council of Trent and the Vatican Council II, is it accurate to brand every attempt of Catholic reformism as »Tridentine« or »Counter-Reformist«? What are the limits of the historiographical use of this terminology?

Even without explicitly addressing these questions, or without proposing a more or less common assessment on the Counter-Reformation, Cid and Cordero's book undoubtedly constitutes a contribution to the debate. One of the book's major advantages is that of expanding to Ibero-
American territory research issues which for too long seemed to belong only to Europe. It succeeds in demonstrating that the Catholic Reform unfolded on the other side of the Atlantic in a unique fashion. And more: it opens the way for new research questions. To a major extent, such a rich outcome is due to the diverse disciplinary background of the authors. Their areas of expertise encompass history, history of art, literature, music, philosophy and theology. Thus, the reader has the opportunity to appreciate the distinctiveness of each approach. Nevertheless, with distinctiveness comes dissonance. In some articles, the analysis of historical sources lacks elements that would be fundamental from a historian's point of view, such as a review of the historiography available. Besides, there are cases in which an author's use of concepts could be considered by a historian as anachronistic or overgeneralizing. In any case, rather than an occasion for interdisciplinary tension, the book serves as an opportunity to consider the methodological view of the other, in an attitude of, so to speak, methodological empathy.

Overall, the case studies that comprise the book are quite successful in offering a general perspective on long-standing issues of the Counter-Reformation, and they are also accessible to an audience that has little in-depth knowledge on the interpretations and uses of the Council of Trent in IberoAmerican territory. It is proof that debates on the Counter-Reformation are the object of constant, fruitful renewal.

\section{Pilar Mejía}

\section{Inquisiciones como reacciones intermitentes*}

La abundante producción historiográfica sobre las inquisiciones nunca se ha detenido. Por suerte, contamos con mecanismos académicos de actualización como este volumen, que nos ofrece un recorrido por las diversas inquisiciones durante dos milenios y sus recientes tendencias historiográ- ficas. Y esto es justamente una de sus virtudes: presentar la historia de los modos de proceder contra posibles errores en materia de fe en sus diferentes contextos y desde una perspectiva comparativa amplia. Gracias a ello, su editor Donald S. Prudlo puede afirmar que, más allá de todas las

\footnotetext{
* Donald S. Prudlo (ed.),

A Companion to Heresy Inquisitions,

Leiden / Boston: Brill 2019, 314 p.,

ISBN 978-90-04-36090-7
} 